\title{
18
}

\section{Managing Deterrence in the 21st Century}

\author{
Stephan Frühling and Andrew O’Neil
}

The introductory chapter to this volume opened with the premise that US allies in Europe and the Indo-Pacific need to become more embedded in, and proficient with, discussions with Washington over escalation and nuclear deterrence. In the Indo-Pacific, long gone are the days when the US and its allies were content with a division of labour that saw Washington manage the risk of great power conflict with little input from its allies. Extended deterrence consultations with Japan and South Korea have created an expectation of greater transparency from Washington over when, where and under what circumstances the US would employ nuclear weapons. But despite this, alliances in the Indo-Pacific remain far from the mature political and military discussions that can provide a common basis for deterrence communication, alignment of force structure and posture, crisis management, as well as managing enduring differences between allies about how they engage their respective populations.

\section{Great Power Competition, Alliances and Deterrence}

The scale of strategic and geopolitical challenges facing Australia, the US and other allies in the Indo-Pacific is daunting. For the first time since before Australia signed its security treaty with the US three-quarters of a century ago, the possibility exists that a hostile peer competitor might 
be able to force the US out of the Indo-Pacific in a great power conflict. Given the stakes involved, a conflict between China and the US and its allies over Taiwan is the most likely contingency that could see such a cataclysmic geopolitical outcome. And China is more likely today than in the past to be successful in such an undertaking - or at least to perceive the odds of forced reunification as favourable enough to try.

Depending on the political and military context at the time, there may be incentives for China to rapidly escalate such a conflict-including to the threat or use of nuclear weapons. As China is most likely to escalate in this manner in the event that it confronts defeat or has its core territory threatened in a conventional conflict, it is not sufficient for the US and its allies to prepare to 'win' through improved conventional capabilities alone. Increased risks of conflict and growing escalation pathways thus challenge US alliances just as improved alliance capabilities and political unity become more important for strengthening the credibility of deterrence. And to mitigate the risk of inadvertent or accidental escalation, improving the prospects for crisis management through prior confidence-building measures that promote transparency is more relevant than traditional arms control. Not only does the latter have a mixed record of success, but also any US attempt to forge arms control with China today would require Washington to engage with Beijing in a way that raises challenges for reassuring Japan, and potentially South Korea and Australia.

For Australia, the resurgence of great power competition underscores established challenges that arise from its geographical location. Given the ongoing focus of the US-South Korea alliance on the threat from North Korea, Australia and Japan are the key US allies in the Indo-Pacific with major (albeit different) roles and capabilities in helping to deter Beijing and, if necessary, assisting the US in fighting a war to defend Taiwan. Such a role carries political and military risk for Australia, which Canberra has long sought to 'manage' by avoiding any of the firm commitments (such as stationing a permanent US force presence on its soil) that would help underpin deterrence at the alliance level. But if deterrence fails and Taiwan is lost, Australia might, as Elbridge Colby points out in this volume, confront the same dilemmas regarding what commitments it would be willing to make to stem further Chinese expansion into the Philippines and maritime South-East Asia. And when increasingly long-range precision strike capabilities reduce the geographic value of Australia for the US, the alliance could itself come into question in the long term. 
The institutional complexion of the alliances discussed in this volume varies significantly, and these differences exert a strong influence over the way they are adapting to the new environment. But there is also a certain convergence that may make these differences less stark now than during the Cold War. This, in itself, changes expectations and poses its own challenges. In the US - Republic of Korea case, the heavily operational focus of alliance cooperation that was forged in the 1970s at a time when South Korea was an authoritarian state is not especially well suited to addressing the political challenges of managing competition with China. In Japan, unequal alliance arrangements rooted in the experience of the Pacific War are increasingly challenged by closer cooperation, the ambitions and implicit assumptions of which may risk outpacing the constraints arising from the pacifist sentiment that remains strongly rooted domestically among Japanese citizens.

In general, the gap between what is required to manage the stresses that escalation-through deterrence and in war-imposes on alliances and the current political-military frameworks to control these remains significant. While NATO's institutional legacy from the Cold War provides an enticing blueprint for managing deterrence with Russia, even here the disappearance of the Warsaw Pact buffer between NATO Europe and Russia means that the dynamics of escalation would today be much faster and, as a consequence, harder to control. Sten Rynning points out that while NATO has found it easier to address the challenges of escalation at the military rather than political level, the theatre-wide approach informing its military strategy raises its own political challenges. At the level of US alliances in the Indo-Pacific, no equivalent concept has yet emerged. Greater cognisance of the need for shared understanding of the dynamics of escalation, if not necessarily shared operational planning for various scenarios, is a common theme that emerges from all the chapters in this volume on these alliances. A conflict over Taiwan may present a geographical focal point for such work that has eluded NATO, but different political constraints remain major obstacles in all three of the US's Indo-Pacific alliances.

A major theme that emerges from the volume, then, is the importance of political unity - as an enabler of closer operational integration but also as something that can be challenged by it. As Michael Rühle writes in his contribution, political unity more so than military power is the glue that binds security alliances together. The prospect of allied involvement against any Russian or Chinese attempt to use force over the specific issue 
at stake, such as Taiwan, serves as a deterrent because it brings into play not just additional force structure and basing locations, but also uncertainty on the part of any aggressor over its capacity to control the scope and level of conflict. As Jeffrey Larsen observes in this volume, deterrence is ultimately psychological and is contingent on adversary perceptions.

Communication of deterrence is, first and foremost, about the affirmation of alliance unity and, as Alexander Mattelaer points out in the case of NATO, engagement of all allies in planning renders the posture of deterrence materially more credible. As was the case during the Cold War, there will be debate and disagreement between those who perceive a preference on the part of China (or Russia) to use force, prioritise immediate deterrence and hence seek to improve military options even at the cost of increasing political tensions on the one hand, and those who see the choice of conflict as a more remote prospect, hence preferring general deterrence to maintain political unity among allies even at the cost of military effectiveness on the other. ${ }^{1}$ But these are trade-offs that occur within an overall alliance deterrence posture that seeks to push the boundaries of what is politically feasible in reducing the perception that allies would not stand with each other-not from an approach to alliances that seeks to preserve the option of doing so, which has been Australia's traditional approach.

The nuclear aspects of deterrence have always been challenging in this regard, and the absence of any notion of nuclear 'burden sharing' as exists in NATO makes this even more so, both politically and practically, for US allies in the Indo-Pacific. However, the silver lining that emerges from this volume regarding nuclear weapons is how much they remain in the background of strategic competition in the Indo-Pacific. Escalation to the use of nuclear weapons against the US homeland by China is most likely if China is losing a conventional conflict. But, like the US, Beijing will have options other than nuclear weapons to target allied homelands with effect (such an unrestrained cyber attacks) as it moves up the escalation ladder. China has no realistic ability to undermine US nuclear retaliatory capabilities, and in general has little incentive to increase the prominence of nuclear forces that could only undermine its scope for conventional primacy in the Indo-Pacific. Moreover, as Oriana

1 On the NATO Cold War experience, see Ivo Daalder, The Nature and Practice of Flexible Response: NATO Strategy and Theatre Nuclear Forces Since 1967 (New York: Columbia University Press, 1991), doi.org/10.7312/daal92104. 
Skylar Mastro notes in her chapter, Beijing has no obvious incentives to use nuclear weapons against US allies in the Indo-Pacific because of the need to preserve its limited stockpile for use against US targets, as well as China's no-first-use declaration.

Besides the need to deter Chinese (or Russian) escalation to nuclear use to terminate a conflict, the general possibility that US nuclear forces might come into play in the case of catastrophic losses remains an important element of managing escalation-and deterring threats to US alliesin this new era of great power conflict. However, neither in Europe nor in the Indo-Pacific can nuclear weapons carry the main burden of deterrence as they did during the Cold War. NATO is explicit about the use of nuclear weapons changing the nature of a conflict but not in articulating the detail of escalation below (or above) that level. Nuclear weapons have a crucial but limited overall role in a strategy that ultimately rests on the ability to deter, fight and prevail through conventional means. In this context, it is also notable that NATO deliberately responded to Russia's violation of the Intermediate-Range Nuclear Forces (INF) Treaty not with the introduction of new nuclear intermediate-range missiles of its own, but through adjustments to its conventional forces and existing, limited nuclear forces. ${ }^{2}$

Societal aversion to nuclear weapons remains strong in Japan as well as Australia, and politically separating nuclear from any conventional elements of deterrence is thus paramount in the Indo-Pacific, as well as in NATO Europe. But even the overall rather minor adaptations to US nuclear forces in the 2018 NPR might raise political difficulties thought long gone in relation to US Navy ship visits, as well as questions about how they fit into the management of escalation in the Indo-Pacific that allies are yet to address. But — and at this point the dark cloud re-emerges more sharply into focus - this relatively minor role of nuclear weapons for alliances is also partly due to the lack of a common understanding of the concept of escalation in general.

In Australia's case, deterrence has emerged as a prominent concept in the country's 2020 Defence Strategic Update. ${ }^{3}$ Yet, the underlying concept remains highly abstract and focused on capabilities rather than the

2 'Remarks', by NATO Secretary General Jens Stoltenberg at the Brussels Forum, NATO, 23 June 2020, www.nato.int/cps/en/natohq/opinions_176715.htm.

3 Department of Defence, 2020 Defence Strategic Update, www1.defence.gov.au/sites/default/ files/2020-11/2020_Defence_Strategic_Update.pdf. 
political credibility or circumstances underlying how these capabilities would be used; the 2020 Defence Strategic Update has done little to specify how (conventional) deterrence articulates with the broader US posture in the region. Indeed, recapitulation in the 2020 Defence Strategic Update of Australia's well-worn formula that 'only the nuclear and conventional capabilities of the United States can offer effective deterrence against the possibility of nuclear threats against Australia ${ }^{4}$ reaffirms a sole-purpose approach to nuclear weapons that is at odds with US nuclear policy.

Even in the highly institutionalised US-South Korea alliance, Seukhoon Paul Choi concludes in this volume that Washington and Seoul are yet to reach a shared understanding of escalation dynamics and the role of deterrence in the evolving strategic environment. However, almost all contributions to this book underscore the importance of such a shared concept, whether as the basis of political unity as an element of deterrence; to manage the political implications of nuclear weapons; to manage the extreme compression of time for decision-making in crisis management; to reduce the risk of technological surprise resulting from new, non-nuclear capabilities; to create a shared basis for interpreting signals implicit in force movements and 'hardware' cooperation; or because it is simply 'inadequate', as Brad Roberts points out, that among many US allies the outer limits of their own nuclear debate only reach as far as discussing US policy.

Importantly, a shared understanding of escalation does not mean agreement on all relevant choices. As Michael Rühle points out in this volume, it is ultimately impossible to resolve all differences of interests between those allies extending guarantees of support and those receiving them. But the Cold War NATO example demonstrates that it is possible to find compromises that enable cooperation to proceed or, as Paul Schulte once phrased it, to 'politically manage' such differences 'by creating a common deterrence culture ... within which joint planning ... could be conducted and normalized'. ${ }^{5}$ While questions of when and how to initiate the use of nuclear weapons are today less of a focal point for such debates than they were during the Cold War, different interests remain, not least regarding the desirable scope for escalation, including in the case

4 Ibid., para 2.22.

5 Paul Schulte, 'Tactical Nuclear Weapons in NATO and Beyond: A Historical and Thematic Examination', in Tactical Nuclear Weapons and NATO, ed. Tom Nichols, Douglas Stuart and Jeffrey McClausland (Carlisle Barracks: Strategic Studies Institute, US Army War College, 2012), 25 (emphasis in original). 
of 'minor' deterrence failures like those that strained the US-South Korea alliance in 2010, the speed of escalation or the desirability of horizontal escalation in major conflict.

\section{Implications of the Book's Analysis}

How can US alliances in the Indo-Pacific start building this common understanding and common deterrence culture? Three distinct, but closely related areas emerge from the contributions to this volume.

First, there is a need to move from consultation about US nuclear posture and deterrence, which can often entail the US simply informing allies of what has happened, to a more genuine joint development of assessments, concepts and planning for deterrence. ${ }^{6}$ Even if deterrence dialogues and committees established in the US-Japan and US-South Korea alliances a decade ago have, to borrow a NATO colloquialism, helped to 'raise the nuclear IQ' in these alliances, the contributions in this volume also point to the limitations, if not divisive aspects, that can arise from constrained formats that remain narrowly focused on the North Korean threat, or include a perception of the US 'educating' its allies. As Brad Roberts points out, there is an opportunity for consultation evolving into substantive collaboration on some aspects of the Biden administration's forthcoming Nuclear Posture Review. This could have the added beneficial effect of reinforcing the credibility of US extended nuclear deterrence after a period of alliance anxiety under the Trump administration. Indeed, there are strong parallels with the way that the US in the 1960s tried to find new, more cooperative ways of engaging its non-nuclear allies on the practical and political challenges of deterrence, which moved from increased access to information on US policy towards joint analysis and political agreement on basic principles. ${ }^{7}$ Because Australia has not been receptive to even the relatively limited dialogues that commenced in North-East Asia in 2011 in its own alliance relationship with the US, the learning curve and political significance of such cooperation would be considerable.

6 For recent discussion of this theme through the lens of non-proliferation, see Ivo Daalder, Chuck Hegel, Malcolm Rifkind and Kevin Rudd, 'Preventing Nuclear Proliferation and Reassuring America's Allies', The Chicago Council on Global Affairs, 10 February 2021, www.thechicagocouncil.org/ research/report/preventing-nuclear-proliferation-and-reassuring-americas-allies.

7 Paul Buteux, The Politics of Nuclear Consultation in NATO: 1965-1980 (Cambridge: Cambridge University Press, 1983). 
Second, there is a need for Indo-Pacific allies to address more systematically their own force structure and 'hardware' cooperation aspects of deterrence in their alliances. In Australia's case, new conventional long-range strike capabilities are emerging, yet thinking about their use and effect remains nascent and focused on the tactical level. In the Japanese and, in particular, South Korean cases, conventional strike capabilities that did not exist in the past now provide these allies with greater options for direct influence on the dynamics of escalation. At the same time, the political and strategic limits of a US nuclear posture in the Indo-Pacific whose visible elements today rest solely on nuclear-capable aircraft based outside the region are also coming into sharper relief, through the increasing vulnerability of such forces, the overuse of strategic bombers for signalling and the lack of any significant adjustment (even in the face of momentous strategic shifts since US nuclear weapons were withdrawn from the region in 1992). As Michito Tsuruoka points out in his chapter, there is scope for thinking about closer practical cooperation beyond escorting US strategic bombers passing through the region. In fact, doing so would not just make an important contribution to demonstrating political unity of alliances, but also may help catalyse closer and more enduring institutionalised cooperation at the operational level, even in the US-Australia alliance.

The third strong theme emerging from the volume is the need for governments to actively engage populations about the issues canvassed in this book. A key lesson from NATO's travails of the 1970s and 1980s is that agreeing on and implementing changes to force structure and posture to improve deterrence capabilities and operational effectiveness are insufficient if these measures fail to reassure allies' own populations. Like deterrence, reassurance is ultimately psychological, but there is a reluctance today in many countries to publicly address requirements for deterrence and escalation management, or even arms control. The argument that there is a binary choice between seeking nuclear (and general) disarmament on the one hand, and relying on deterrence on the other is a false one, as it ignores that the ultimate goal of increased security depends on the broader strategic environment in which it is sought. As Tanya Ogilvie-White argues in this volume, restricted engagement of the public on nuclear matters has ultimately backfired and strengthened the hand of disarmament advocates whose case is already a more compelling one to make. 
Statements by NATO governments highlight that they recognise 'that progress on arms control and disarmament must take into account the prevailing international security environment', that they 'regret that the conditions for achieving disarmament are not favourable today'8 and that the Treaty on the Prohibition of Nuclear Weapons 'does not reflect the increasingly challenging international security environment' ? In contrast, the Australian Government continues to discuss disarmament with no reference to the security and deterrent value of nuclear weapons. ${ }^{10}$ Indeed, the joint communiqués following annual Australia-US ministerial meetings lack any reference to the strategic role of nuclear weapons in allies' security. If allies are to continue to share the benefits from US nuclear deterrence, making the case-or, in Brad Roberts's words, 'campaigning' - for it in the prevailing strategic circumstances must be a shared responsibility. As Alexander Mattelaer points out in this volume:

The fundamental willingness to engage in nuclear deterrence is perhaps the hardest question of all. Yet without such political willingness on the part of US allies, it is equally fair to ask whether the US extended deterrence commitment can be fully relied upon. Simply put, can one ask one's ally to do what one is not as a matter of principle willing to do for oneself?

In the end, developing a shared understanding of escalation dynamics, maintaining political unity about a shared approach to deterrence, moving from consultation to joint assessment, policy and planning, alliance reviews of force structure and posture implications for escalation, and public campaigning for the importance of nuclear deterrence are all mutually supporting. Together, these measures would be transformative for US alliances in the Indo-Pacific because they involve accepting a degree of heightened strategic risk that many allies have so far eschewed. Yet, while the risks of entrapment will always be a factor in the calculations of any ally, failing to clarify expectations and commitments in relation

8 'Warsaw Summit Communiqué, NATO, 8-9 July 2016, para 65, www.nato.int/cps/en/natohq/ official_texts_133169.htm.

9 'North Atlantic Council Statement as the Treaty on the Prohibition of Nuclear Weapons Enters Into Force', Press Release, NATO, 20 December 2020, para 1, www.nato.int/cps/en/natohq/ news_180087.htm.

10 Department of Foreign Affairs and Trade, 'Towards a Nuclear Weapons Free World', www.dfat. gov.au/international-relations/security/non-proliferation-disarmament-arms-control/nuclear-issues. 
to deterrence and escalation pathways runs the risk of the US and its allies not being able to take unified action during crises-indeed, of not deterring them from arising in the first place. The adverse implications for the future of alliances in the Indo-Pacific that would inevitably flow from this should be enough to energise policymakers in all alliance capitals to strive for closer cooperation on deterrence and escalation. 
This text is taken from Alliances, Nuclear Weapons and Escalation: Managing Deterrence in the 21st Century, edited by Stephan Frühling and Andrew O'Neil, published 2021 by ANU Press, The Australian National University, Canberra, Australia.

doi.org/10.22459/ANWE.2021.18 